\title{
STUDENTS' COMPETENCE IN TEACHING ENGLISH TO YOUNG LEARNERS: DESCRIPTIONS THROUGH TEACHING SIMULATIONS
}

\author{
Dodi Siraj Muamar Zain \\ Universitas Muhammadiyah Purwokerto \\ dodisiraj@ump.ac.id
}

\begin{abstract}
English is taught as one of local content in most elementary schools in Indonesia. However, there is still lack of concern on preparing students to teach English in elementary school in for will-English teacher students. This paper aims at describing the activities and strategies used by students in teaching English for young learners through teaching simulations in TEYL (Teaching English for young learners) class. There were six groups of students consisting of four students per group to perform a teaching simulation with different topics for approximately 30 minutes. It is expected that this paper provides a description of students' teaching competence after taking TEYL class that later lead to further improvement of this class.
\end{abstract}

Key words: TEYL, teaching simulation

\section{Introduction}

Being no longer a compulsory subject in elementary school curriculum, English is still considered necessary to teach. This phenomenon is driven by consideration that English communicative competence is required to compete in globalization era. The ability to communicate in English sometimes becomes a parameter how potential a school is. It could be seen by a national regulation applied in the early 2000 where schools were directed to be standardized internationally by implementing English as a medium of communication. Though this regulation no longer exists, the assumption that English is necessary and even important for the future success of students. Crystal (2003) [1] stated that around a quarter of world population use English as the main medium of communication and will possibly increase significantly in the future.

The main purpose of teaching English is to improve students competence to communicate in daily life or any other contexts (Wijaya, 2015) [2]. However, Teaching skills of English for young learners is unique as its implication will show major differences than that of adult learners. Psychologically, young learners are individuals with unpredictive personalities. They cannot be considered a miniatured adult learners that the treatments must be careful as it may influence their maturity. Unlike adult learners where teaching materials can be transferred explicitly through an organized teaching steps, teaching young learners must be in accordance with the world they are in. in a simple way, teachers need to provide a learning atmosphere where students will feel that they are force to learn. Therefore, teachers must make use of certain strategies like using games, songs, and videos and treat them carefully to direct them to do as teachers expect.

The current implementation of curriculum in English department show little emphasize on teaching English o young learners. Most subjects focusing on teaching skills direct students to be competent in teaching English at intermediate level. As for the field teaching practicum, students are also assigned only to middle or high schools. more concern on teaching English for young learners is necessary as teachers will be the main factor to determine the success of teaching and learning process (Listia, 2009) [3].

This paper provides students teaching practices in TEYL upon completing TEYL class. TEYL is an elective course students can take a part. It revealed students preferences in terms of activities, media and strategies they can later implement in the real classroom practice. 


\section{DIFFERENCES ON TEACHING ENGLISH FOR YOUNG AND ADULT LEARNERS}

Teaching English for young learners required certain skills and dedication due to their characters. Different from adult learners who can be considered more independent, the success on TEYL relies much on how teachers organize the students carefully. Young learners cannot be forced to learn without their own willingness. Children have unique characteristics that could be employed for the supporting factors and disadvantaging factors of foreign language learning process. They are likely to be active, rely on short term memory, learning by doing, spontaneously do their action, not afraid of doing mistakes no care for their actions or even the lessons (Nurhayati, 2009)[4].

Certain approaches must be harnessed such as using games, pictures, songs/ videos, and several encouragement to provide them an enjoyable learning atmosphere. In addition, teachers need to try to comprehend what students feel about the circumstances as they are easily exposed with boredom once they lose their interest on learning activities as a result, it lead to their reluctance to do what teachers instruct. It is certainly different from adult learners that they can be forced to adapt themselves with provided learning circumstances. Despite its difficulties in teaching English to young learners,

While there are several theories reveal golden period of young learners in learning language, the recent studies claim that adult learners still excel in learning gain. Another expert, Vygotsky (1978, cited in Hughes, 2009) [5] believed that language was central to the cognitive development of children, that it was instruction provided by an adult that helped children learn and develop. Harmer (2007) [6] states that older learners still excel in learning compared with young learners. this claim is supported by Lightbown and Spada (1999) [7] referring to several studies showing the achievement shown by adult learners in comparison with young learners. However, with careful treatment, teaching English in the early stage of development will result in an excellent result as it is generally known that young learners' memory accept language with high precision lading to native like English performance (Harmer, 2007).

\section{STRATEGIES IN TEYL}

\section{A. Focusing on oral communicative competence}

It is generally known that there is an irregularities in the way English words are pronounced, in other words, it is almost not possible to read English words as the combination of sound of the composed letters will sound different from the sound of its individual letter. Therefore, students should not be taught how to read word and should focus on pronunciation through drilling. Drilling diminish the possibility of fossilization (repeated language errors) which may occur in language learning. This technique also supports students' improvement on the stock of vocabulary. However, this kind pf activity should be carefully prepared as students might find it boring due to its monotonous characteristics.

\section{B. Using varied and challenging activities}

Young learners have unpredictive behavior during classroom teaching. They have higher possibilities to get exposed to boredom than adults. Therefore, teachers are required to implement varied activities to provide different learning atmosphere. Several challenging games, songs, videos, realia and movement; engaging students in classroom activities; using physical activities; teaching in certain topics; delivering familiar materials to students; encouraging classroom habits in English; using L1 when required; finding assistants from the society; teamworking with other teachers; and consulting with experts (Shin 2006) [8].

Teaching using games can be a choice to develop an enjoyable classroom atmosphere for young learners. Language games consist of well planned and organized activities which may make use of few language elements yet engage students cognitively and emotionally in dealing with language learning (Fleta, 2009 as cited by Geurgeou. 2010) [9]. In language classes, games may provide an opportunities to develop their vocabulary and pronunciation skill by harnessing teamwork or individual skill. However, teachers cannot merely select any games for learning. They need to be selective and adjust them with the expected learning objectives. Games can be time consuming and ineffective without optimal preparations. Teachers also need to use simple and understandable instructions to manage the students. Using games, students will be exposed with a meaningful language learning and teachers can identify their needs (Crandall, 1998) [10].

\section{Modeling}

Unlike adult learners, young learners have their own limitation to comprehend oral instruction. They might be familiar with short and repeated instruction. Yet, when it comes to a kind of new activity and teachers are required to instruct them to do it, they might find it difficult to comprehend teachers' instruction. They still 
lack the capability to process something abstract and picture it in their mind. Therefore, modeling can be the choice in directing students to do the classroom task efficiently.

\section{Various types of reinforcements}

Young learners motivation are reliant to kinds of reinforcement during classroom activities. Therefore, teachers need get used to harness any types of reinforcement and adjust them to students' character. Providing more lively class can be simple and effective by harnessing varied reinforcements to build students' interest (Newcomer, 2009; Simonsen, Fairbanks, Briesch, Myers, \& Sugai, 2008 as cited in Peters, 2010) [11]. However, there should be a certain strategy to use that students will perform the behavior teachers expect (Turtoun \& others, 2007) [12]. The types of reinforcement should be taken into account as not all students will respond positively to any reinforcement they receive.

\section{SUBJECT}

The subject of this study was 18 students of microteaching class. These students were divided into six groups consisting of three members for each group. These groups were given 30 minutes to construct a lesson plan and simulate a teaching practices. Considering the time allotment, students were expected to have three activities for each simulation. There were also around 10 other students playing the role of students.

\section{METHODOLOGY}

Descriptive method was implemented in this study. The data were taken from the video recording on students' teaching simulation for around 30 minutes. the data were then transcribed and interpreted to get the highlights of each activity.

\section{FINDINGS}

During the microteaching, student teachers were ordered to demonstrated a teaching simulation which last for 30 minutes. Teaching activities for each simulation comprised three to four steps consisting of opening, main activities and closing with different topics. Each topic was randomly assigned to each group. From the demonstrated teaching practices, the descriptions are as follows.

\section{A. Group 1}

Image 1. Sequence of Activity of Group 1

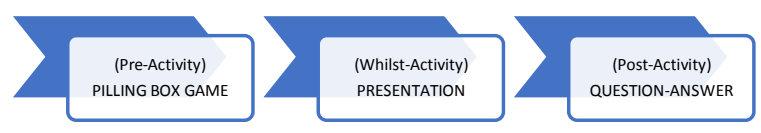

The topic used for group one is parts of the house. The lesson was aimed at introducing the vocabularies dealing with parts of the house. Games in the form of piling boxes were used in pre-activity class. The student teachers started by dividing students into two groups. The students were then asked to compete to pile the most boxes.

The next activity for the whilst-activity was presentation. In this activity, the student teachers used pictures to show the parts of house and what students could find there. By pointing at each part of picture, the student teachers pronounce the name of house parts and asked the students to repeat. This activity was then followed by a sticking game which required students to stick the pictures of the rooms with pictures of items students could find there.

The post-activity was carried out by giving students questions and let them answer the questions individually. The student teachers pointed at items on each room and ask students to name them.

\section{B. Group 2}

Image 2. Sequence of Activity of Group 2

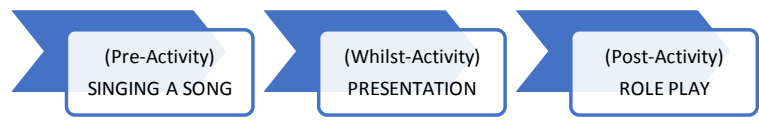

The topic of group two was a bout parts of body. The class started with singing a song. The student teachers played a song, asked students to listen to it and sing the song together. While singing, some a physical activity of dancing was done.

The whilst activity was introducing the parts of body using pictures. Student teachers showed some pictures of parts of body and named them. Drilling was used in this activity as the student teachers asked students to repeat the words mentioned by them. This activity was then followed by singing a song.

In the post activity, student teachers were having a role play. Students played the role of patients while student teachers played the role of doctors. Students needed to mention the parts of body which 
suffered from pain in English and student teachers gave the solution for the problems.

\section{Group 3}

Image 3. Sequence of Activity of Group 3

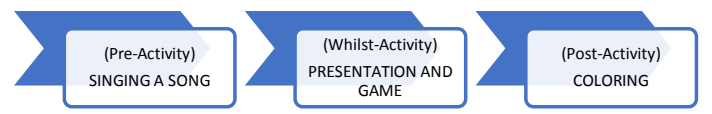

The topic for group three was animals. Students started the lesson by singing songs. Student teachers first demonstrated the song and later students were asked to sing together.

In the whilst activity, students were introduced with some animals of the zoo using pictures. Student teachers introduced the vocabulary with song. Student teachers later distribute several piece of paper which was cut in the forms of several animals to students. Students are then asked to identify the shapes of animal from the piece of paper and stick the paper on the wall.

The last activity was coloring. The student teachers distribute a piece of paper with some pictures of animals to students. Students were then asked to color the pictures with appropriate colors.

\section{Group 4}

Image 4. Sequence of Activity of Group 4

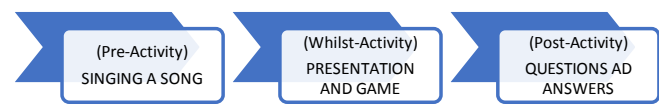

The topic for group four was things around us. This topic was focused on items students could find in the classroom. The pre-activity was singing a song. At first, student teachers sang a song and asked the students to listen. The students later asked to sing together with the student teachers.

The main activity was presentation. In this step, student teachers provided several pictures of items students could find in their classroom. The student teachers named them one by one and later asked students to repeat what they mentioned. Later, they had a ladder snake game. They prepared an arena consisting of small numbered squares where they had already put a piece o paper. On this paper students could find pictures of items. In this game, students needed to spin a dice to get the number and put themselves on a position of the numbered square which matched their number. They were then required to named the item on the pictures.

The final activity was question and answer. Students were shown some pictures and asked to named them individually. The ones who managed to answer got some rewards from the student teachers.

\section{E. Group 5}

Image 5. Sequence of Activity of Group 5

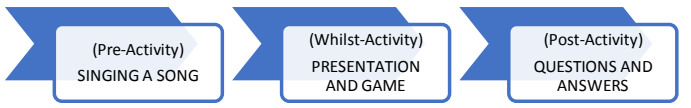

Group five carried out a teaching simulation with the topic of fruit in. In the pre-activity, the student teachers guided students to sing a song. Students were to listen and later asked to sing together.

In the whilst-activity, students were given some vocabulary about fruit. Using fruit-shaped paper, student teachers named the fruit one by one and asked students to repeat after them. Student teachers later handed some paper to students and asked them to name the paper fruit they were holding. The students were then having a singing activity continued with a puzzle game. Students were to arrange the pieces of paper and named the fruit shown from the arranged paper.

The post-activity dealt with evaluation. Students were asked to name the fruit shown by the student teachers individually. Those who managed to answers were given rewards.

\section{F. Group 6}

Image 6. Sequence of Activity of Group 6

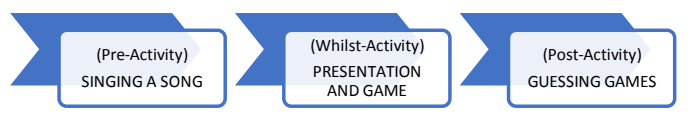

The topic of teaching for group six was shapes and colors. In the pre-activity, student teachers started the lesson with an ice breaking activity in the form of singing. The students were first asked to listen to their student teachers singing. They then sang the songs altogether.

Students are then directed to focus on the student teachers presentation during whilst activity. Students teachers used several pictures to introduce colors and shape. This activity also emphasized the use of drilling where students are directed to rephrase teachers pronunciation of words for several times. After presentation, teachers used games in the form of whispering game. In this game, students were divided into two groups and stood on a line. Several pieces of colored paper with different shapes were spread on the floor. Students were to whisper certain colors or shapes and the last student at the end picked the paper with matched colors or shapes. 
In the post activity, student teachers were asked to draw shapes and color it on a piece of paper. The student teachers made a competition that student that complete the task correctly and fastest among others was given a certain reward.

\section{DISCUSSIONS}

Within the given time allotment, arranged teaching steps, predetermined topics, student teachers demonstrated a simulation of teaching practices of English for young learners. There were three to four activities that were implemented in the lesson. The student teachers made use of various activities and media to support the success of teaching.

As directed, students focused on oral language communicative competence. there were no writing or reading activities carried out by student teachers. As it is suggested, young learners should be more exposed with correct pronunciation of words through drilling as it will diminish the possibility of word mispronunciation leading to fossilization. It is known that they would receive inputs especially sound, store it in their memory and reproduce them accurately.

Students in the pre-activity, student teachers mostly used song in their teaching. They combined this activities with some physical activities like dancing. The use of song has been proved effective to trigger students motivation in learning. Songs provide an atmosphere of learning where students can enjoy themselves and naturally learn the language as by Cakir (1999) [13]. Using songs requires only simple instructions and can be easily practiced by students especially young learners.

The main activities are mostly dominated with verbal communicative activities. This activity was expected to help students memorize the pronunciation of words accurately. The other thing to notice during his step was the use of pictures. It is actually in line with the theory stating that young learners still found it difficult to picture something abstract.

The use of games also took an important part in teaching. As games are considered effective to increase student's motivation in learning. This activity can be a way to encourage students to use the target language. Dunn (1983) [14] stated that certain games are effective to develop language competence for young learners. They give the opportunity to learners to learn and use language in a meaningful way and help teachers to understand the students' needs (Crandall, 1998 as cited in shin, 2006) [15]. Using games, students will not fell frustrated to learn something new. Several games that can be used in TEYL are matching game, guessing game, coloring etc.

Kuo (2008) [16] claimed that games can be an ultimate choice to motive unmotivated students. Several experts (Chan \& Lin, 2000; Jiang, 2008; Kuo, 2008; Robinson, 1960; Zheng, 2008 as cited in Wang, Shang, \& Briody, 2011) [17] propose that learning objectives can be optimally achieved through games under appropriate circumstances.

Most students might think that games are only for fun.. therefore, teachers are required to select the suitable games and prepare them before being implemented in the classroom. They need also to consider how to build connection between the game with the learning materials and predict the strengths and weaknesses of the games (Khan, J.1996) [19].' The key to a successful language game is that the rules are clear, the ultimate goal is well defined and the game must be fun. Several groups also used competition with certain rewards to improve students' enthusiasm. Competitions will improve the value of a game as it gives more challenges to students to perform better than their peers. Supporting with rewards, students will try their best to perform better than other in carrying out teaching tasks.

\section{CONCLUSIONS}

Student teachers used various activities during microteaching in TEYL class. As directed they also used several media and focus teaching practices on speaking skills. During the allotted times, student teachers employed icebreakers activities in the form of singing songs, watching videos and having total-physical responses activities in the pre-teaching stage. During the whilst teaching stage, they presented the materials using pictures and videos and focused on drilling to enhance students pronunciation skills. This presentation activities were followed by games or other activities which harnessed groupwork. The post-activity dealt with evaluation. Student teachers had a review of students' understanding by asking several questions about the vocabulary they had gained. This step focused on individual progress.

\section{References}

[1] Crystal, David. (2003), English as a Global Language, Cambridge University Press, New York.

[2] Wijaya, I. K. (2015). Pembelajaran Bahasa Inggris di Sekolah dasar. Bahtera: Jurnal Pendidikan Bahasa dan Sastra, 14(1), 120-128. 
[3] Listia, R., \& Kamal, S. (2008). Kendala Pengajaran Bahasa Inggris di Sekolah Dasar. Retrieved on September 8, 2017.

[4] Nurhayati, L. (2009). Penggunaan Lagu dalam Pembelajaran Bahasa Inggris untuk Siswa SD; Mengapa dan Bagaimana. Majalah Ilmiah Pembelajaran, 5(1).

[5] Hughes, B. (2009). How to start a STEM team: with little chance to learn in school how science and math skills might translate into professionally useful knowledge, students are unable to make informed choices about further education and work options. The Technology Teacher, 69(2), 2730.

[6] Harmer, Jeremy. (2007). The practice of English language Teaching. Pearson Education Ltd.

[7] Lightbown, P. M., Spada, N., Ranta, L., \& Rand, J. (1999). How languages are learned (Vol. 2). Oxford: Oxford University Press.

[8] Shin, J. K. (2006). Ten Helpful Ideas for Teaching English to Young Learners. In English Teaching Forum (Vol. 44, No. 2, p. 2). US Department of State. Bureau of Educational and Cultural Affairs, Office of English Language Programs, SA-5, 2200 C Street NW 4th Floor, Washington, DC 20037.

[9] Ioannou-Georgiou, S. (2010). Teaching English to very young learners: Using games. Lecture Notes.

[10] Crandall, J. (1998). Collaborate and cooperate: Teacher education for integrating language and content instruction. English Teaching Forum 36 (1): 2-9.

[11] Peters, L. C. (2010). Reinforcement in the classroom improves student motivation and performance. Innovations and Perspectives.

[12] Turton, A. M., Umbreit, J., Liaupsin, C. J., \& Bartley, J. (2007). Function-based intervention for an adolescent with emotional and behavioral disorders in Bermuda: Moving across culture. Behavioral Disorders, 23-32.

[13] Cakir, A. (1999). Musical activities for young learners of EFL. The Internet TESL Journal , 5. Retrieved on August 20,2017, from http://www.iteslj.org/Lessons/Cakir

[14] Dunn, R. (1983). Learning style and its relation to exceptionality at both ends of the spectrum. Exceptional Children, 49(6), 496-506.
[15] Shin, J. K. (2006). Ten Helpful Ideas for Teaching English to Young Learners. In English Teaching Forum (Vol. 44, No. 2, p. 2). US Department of State. Bureau of Educational and Cultural Affairs, Office of English Language Programs, SA-5, 2200 C Street NW 4th Floor, Washington, DC 20037.

[16] Kuo, Y. L. (2008). The effect of games in fifth graders' English speaking ability in an elementary school in Taipei County. Unpublished masteres thesis, National Taipei University of Education, Taipei, Taiwan.

[17] Wang, Y. J., Shang, H. F., \& Briody, P. (2011). Investigating the impact of using games in teaching children English. International Journal of Learning and Development, 1(1), 127-141.

[18] Khan, J. (1996). 'Using games in teaching English to young learners' in (eds)Brumfit, $C$, Teaching English to Children. From Practice to Principle England: Longman. 